\title{
33. ANALYSIS OF TEN LEG 22 CORES FOR ORGANIC CARBON AND GASOLINE-RANGE HYDROCARBONS
}

\author{
Richard D. McIver, Esso Production Research Company, Houston, Texas
}

Ten samples of Leg 22 cores, frozen especially for organic geochemistry, were analyzed by previously reported methods (Dunton and Hunt, 1962; Gehman, 1962) for their organic carbon contents and their $\mathrm{C}_{4}-\mathrm{C}_{7}$ (light gasoline) hydrocarbon contents. Results are shown in Table 1. It was hoped that in the deeper samples in this group the onset of generation of gasoline-range hydrocarbons might be seen. However, as Table 1 shows, the quantities of these hydrocarbons are so low that no conclusions can be drawn. The amounts are in the lower range of values $(0.064$ to 0.408 ) found in the generally shallower organic-rich Pleistocene and Holocene sediments of the Cariaco Trench (McIver, in press).

Further inspection of the gas chromatograms, however, may give some clues to the type of gasoline hydrocarbons which are first generated in the maturation process. The most prominent "bump" above background noise on the gas chromatographic traces (except those with no $\mathrm{C}_{4}-\mathrm{C}_{7}$ hydrocarbon reported) is at the correct retention time to be tentatively identified as $n$-hexane. Others, in order of the apparent size of peaks (i.e., abundance) are tentatively identified as methyl cyclopentane, cyclohexane, 3-methylpentane, and 2-methylpentane.

Interestingly enough, all of these supposed early maturation products are 6-carbon atom compounds. This complete lack of 5- and 7-carbon atom hydrocarbons rules out cracking as a source of the observed hydrocarbons. They must come from decarboxylation of a limited suite of naturally occurring straight and branched fatty acids and naphthenic acids such as those summarized in Erdman (1967).

The amounts of organic carbon are well within the range found for other Deep Sea Drilling Project deep ocean samples.

\section{ACKNOWLEDGMENTS}

The author wishes to acknowledge Ralph Pokluda, Bobby Barrientos, Rosie Ramirez, and Harvey Fry who assisted with the sample and data handling and analysis.
TABLE 1

Content of Organic Carbon and

Gasoline-Range Hydrocarbons

\begin{tabular}{|c|c|c|c|c|}
\hline Sample & $\begin{array}{c}\text { Interval } \\
(\mathrm{cm})\end{array}$ & Age & $\begin{array}{c}\text { Total } \\
\text { Organic Carbon } \\
(\%)\end{array}$ & $\begin{array}{c}\text { Gasoline-Range } \\
\left(\mathrm{C}_{4}-\mathrm{C}_{7}\right) \\
\text { Hydrocarbons } \\
\text { (ppm) }\end{array}$ \\
\hline $218-2-6$ & $0-20$ & Pleistocene & 0.42 & 0.000 \\
\hline $218-5-2$ & $10-20$ & Pleistocene & 0.44 & 0.000 \\
\hline $218-6-2$ & $0-10$ & Pleistocene & 0.23 & 0.031 \\
\hline $218-8-3$ & $20-40$ & Pleistocene & 0.72 & 0.000 \\
\hline $218-13-2$ & $0-20$ & Late Miocene & 0.21 & 0.021 \\
\hline $218-17-3$ & $0-20$ & Late Miocene & 0.26 & 0.033 \\
\hline $218-21-3$ & $20-40$ & Late Miocene & 0.21 & 0.024 \\
\hline $218-26-2$ & $0-10$ & Middle Miocene & 0.30 & 0.032 \\
\hline $217-24-0$ & $0-20$ & Late Cretaceous & 0.03 & 0.000 \\
\hline $217-31-2$ & $0-20$ & Late Cretaceous & 0.03 & 0.046 \\
\hline
\end{tabular}

\section{REFERENCES}

Dunton, M. L. and Hunt, J. M., 1962. Distribution of low molecular weight hydrocarbons in recent and ancient sediments: Am. Assoc. Petrol. Geol. Bull., v. 46, 2246-2248.

Erdman, J. G., 1967. Geochemical origins of the low molecule weight hydrocarbon constituents of petroleum and natural gases: World Petroleum Cong. Proc., 7th, Mexico, v. 2, p. 13-24.

Gehman, H. M., Jr., 1962. Organic matter in limestones: Geochim. Cosmochim. Acta, v. 26, p. 885-897.

McIver, R. D., in press. Cyclical Geochemical properties of organic matter in Cariaco Trench cores. In Heezen, B. C., MacGregor, I. D., et al., Initial Reports of the Deep Sea Drilling Project, Volume XX. 